\title{
Effects of Metformin vs. Glibenclamide on Serum Leptin Concentration in Type 2 Diabetic Patients
}

\author{
Isam H. Mahmood \\ Department of Pharmacology \\ College of Pharmacy \\ University of Mosul \\ Isam_mahmood@yahoo.com
}

\author{
Haimn A. Tawfiq \\ Department of Pharmacology \\ College of Medicine \\ University of Mosul \\ haimn2009@yahoo.com
}

(Received 26/8/2012; Accepted $17 / 12 / 2012$ )

\begin{abstract}
This study was done to assess the effects of metformin and glibenclamide on serum leptin concentration in type 2 diabetic patients. The study involved 137 patients suffering from type 2 diabetes mellitus. They were divided into 3 groups. The first group involves 35 newly diagnosed diabetic patients, who did not take any hypoglycemic agents. The second group involves 52 patients on metformin monotherapy, whereas the third group involves 50 patients on glibenclamide monotherapy. Another group which involved 35 apparently healthy subjects was used as control group. These four groups were matched. age, gender, and BMI Serum glucose concentration was estimated by the enzymatic method, while serum leptin concentration was measured using ELISA kit. The results showed that serum leptin concentration was lower in metformin group than that in glibenclamide group. In addition, there was a significant correlation between serum leptin level and BMI. No correlation was found between serum leptin level and fasting serum glucose. Therefore, the results indicated that metformin, in compared with glibenclamide, can significantly reduce the serum leptin concentration in overweight diabetic patients, consequently reducing the resistance against hormone action, and improving its action, which may lead to explain the known anorexigenic effect of metformin and its ability to reduce or prevent weight gain. In conclusion, plasma leptin level can be used as an indicator for the choice of treatment in those diabetic patients.
\end{abstract}

Keywords: Leptin, Metformin, Glibenclamide, Type 2 Diabetes Mellitus. 


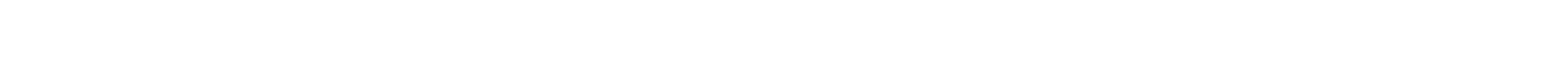 من النوع الثالي}

\section{الملغص}

"أجريت هذه الدرلسة لقيلس مدى تأثير عقاري المقورمن والجلايبينكلمايد على تركيز هرمون اللبتين في

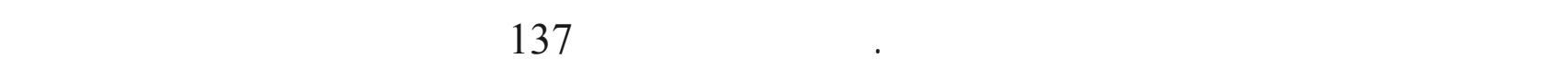

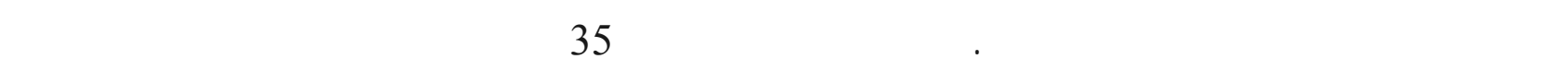

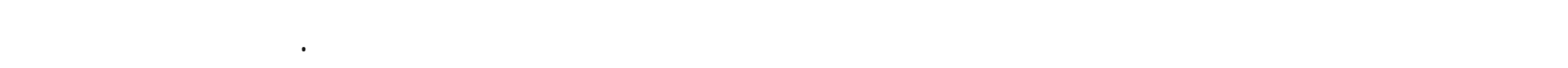

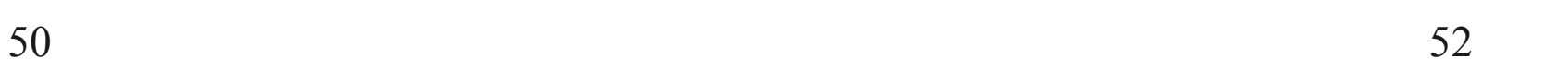

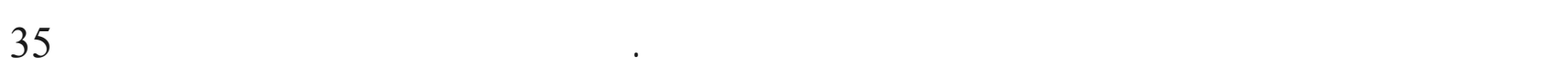

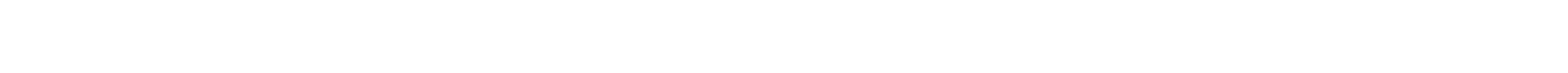

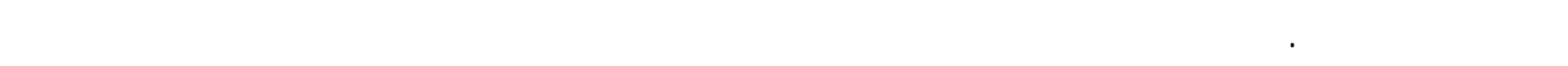

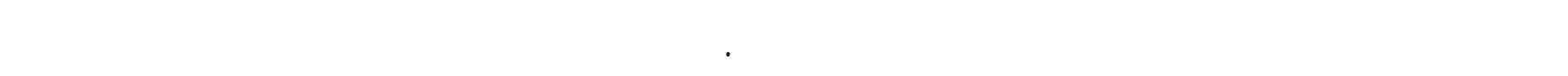

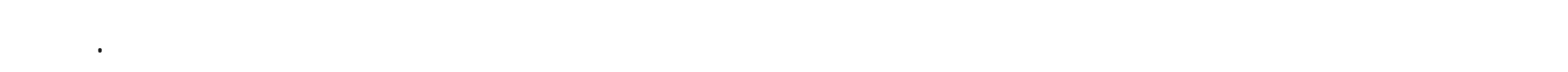
لظٔهرت النتائج وجود علاقةطرية بين معلمل كتلة الجسم وتركيز هرمون اللبتين في المصل بينما لاتوجد علاقة

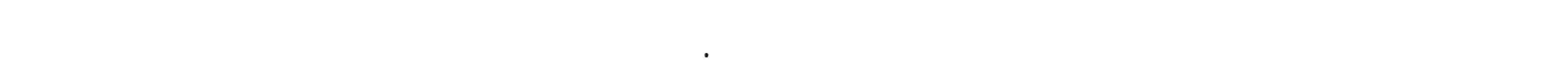

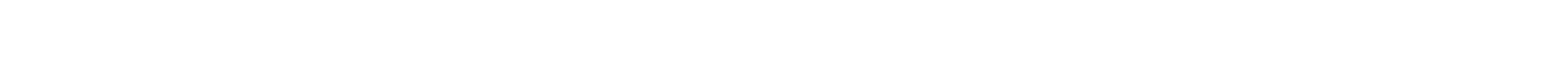

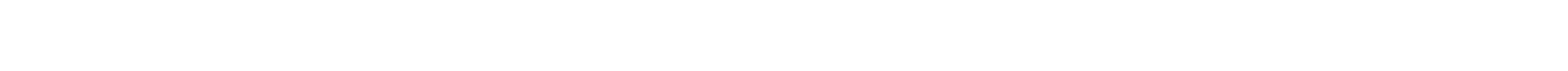

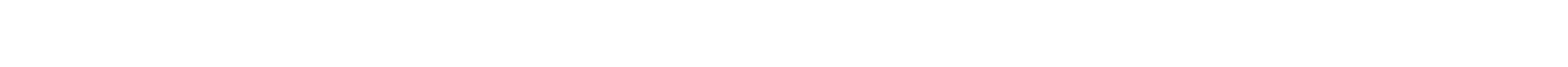
أومنع زياته لدى هذا النوع من المرضع.

الكاملت الدالة: اللبتين، المقورمين، الجلايبينكلمايد، داء للسكري من النوع الثاني

\section{INTRODUCTION}

Diabetes mellitus (DM) is a group of metabolic disorders characterized by hyperglycemia, which is associated with long-term microvascular and macrovascular complications (ADA, 2012).

Leptin (leptos means thin), is a peptide hormone (167 amino acid protein), which is discovered at the end of the year 1994. It is produced by adipocytes and acts on the satiety centre on the hypothalamus to suppress appetite, limit food intake and increase energy 
expenditure. Its deficiency or resistance can result in profound obesity, diabetes and infertility in humans (Bhattacharya et al., 2008). Since its discovery, our understanding of leptin's biological functions has been expanded from anti-obesity to broad effects on reproduction, hematopoiesis, angiogenesis, blood pressure, bone mass, lymphoid organ homeostasis, and Tlymphocyte systems (Zhang et al., 2005).

A number of investigators studied the level of serum leptin in type 2 diabetic patients. Misra et al., (2001) demonstrated high leptin values in all obese individuals, and obese diabetic patients showed the highest levels. In another study, the mean leptin concentration in obese diabetic patients was $(22.5 \pm 6.5 \mathrm{ng} / \mathrm{ml})$ and was not significantly different from that in obese patients without diabetes $(24.1 \pm 10.3 \mathrm{ng} / \mathrm{ml})$ but differed markedly in comparison to the normal weight diabetic patients $(7.9 \pm 4.3 \mathrm{ng} / \mathrm{ml}, p<0.01)$ (Kwalska et al., 1998). The main novel finding in another study was that serum leptin was significantly lower in diabetic patients compared with controls in both females and males, although BMI did not differ between diabetic and non-diabetic subjects (Abdelgadir et al., 2002).

Metformin is a biguanide hypoglycemic agent used for the treatment of type 2 diabetes mellitus by reducing insulin resistance without directly affecting insulin secretion (Bailey, 1992). Metformin has been reported to have no effect or modest reduction on plasma leptin level with short-term use, and to reduce plasma leptin with long-term use (Doogue et al., 2009). Clinically, it has been suggested to reduce food intake in diabetic and non-diabetic patients through specific effects at the level of the hypothalamic centers regulating satiety and feeding (Aubert et al., 2011).

Glibenclamide is a second-generation sulfonylurea drug used for the treatment of patients with T2DM (Laxmi et al., 2009). Insulin secretagogues, including sulfonylureas, correct hyperglycemia by stimulating insulin secretion (Lebovitz, 2002). Insulin stimulates the secretion of leptin, which explains the elevated level of leptin by sulphonylureas (Hamed et al., 2011). Hyperleptinemia is associated with obesity and has been used as an index of leptin resistance and bulking of adipose tissue (Correia and Hayness, 2008).

The aim of the present study was to investigate the effects of metformin and glibenclamide monotherapy on serum concentration of leptin in patients with T2DM.

\section{PATIENTS AND METHODS}

The study involved 172 subject divided into four groups. The first group (control-1) consists of 35 apparently healthy individual with a mean age of $50.7 \pm 9.1$ years. The second group (control-2) consists of 35 newly diagnosed type 2 diabetic patients with a mean age of $50.08 \pm 8.6$ years. The third group consists of 52 patients on metformin with a mean age of $51.07 \pm 7.4$ years, whereas the fourth group consists of 50 patients on glibenclamide with a mean age of $50.9 \pm 7.76$ years. The four groups were matched regarding age, gender and BMI.

Research and ethical committees at the college of medicine and Mosul Health Administration approved the study protocol. The study was a case controlled, comparative study, performed at Al-Waffaa diabetic center in Mosul city during the period between $1 / 10 / 2011$ and $1 / 7 / 2012$. 
Type 2 diabetic patients treated with metformin or glibenclamide monotherapy for a period of not less than 6 months were included in this study. Patients with renal failure, Cushing syndrome or hepatic diseases were excluded from the study after the clinical evaluation. Patients taking oral hypoglycemic agents other than metformin or glibenclamide and those taking drugs that may affect the results of the study such as hypolipidemic agents had also been excluded. Pregnant and lactating women were also excluded from the study.

Serum glucose concentration was estimated by glucose-oxidase-peroxidase colorimetric method using a kit supplied by Biocon (Spain). Serum leptin was measured using the GenWay human leptin ELISA kit (USA) which is based on standard sandwich enzyme linked immunosorbent assay (ELISA) technique for quantitative in vitro measurement of human leptin in serum, plasma and body fluids.

Statistical methods: Chi Square test was used to detect the differences between genders. Oneway analysis of variance (ANOVA test) and Duncan's tests were used to compare the measured parameters of the four groups. Results were considered significant at $p \leq 0.05$.

\section{RESULTS}

Table (1) shows control and patients characteristics. Non-significant differences were found between genders, age and BMI of the four groups.

Table 1: Patients and control characteristics.

\begin{tabular}{|c|c|c|c|c|c|}
\hline \multirow{2}{*}{ Groups } & \multicolumn{4}{|c|}{ Mean \pm SD } & \multirow[b]{2}{*}{$p$-value } \\
\hline & $\begin{array}{c}\text { Non- } \\
\text { diabetics } \\
(\text { Control-1) } \\
(n=35) \\
\end{array}$ & $\begin{array}{c}\text { Newly diagnosed } \\
\text { (Control-2) } \\
(n=35)\end{array}$ & $\begin{array}{c}\text { Metformin } \\
(n=52)\end{array}$ & $\begin{array}{c}\begin{array}{c}\text { Glibenclami } \\
\text { de } \\
(n=50)\end{array} \\
\end{array}$ & \\
\hline $\begin{array}{l}\text { Male } \\
\text { Gender }\end{array}$ & $16(45.7 \%)$ & $16(45.7 \%)$ & $25(48.1 \%)$ & $26(52 \%)$ & N.S $\dagger$ \\
\hline Female & $19(54.3 \%)$ & $19(54.3 \%)$ & $27(51.9 \%)$ & $24(48 \%)$ & \\
\hline Age (years) & $50.7 \pm 9.1$ & $50.08 \pm 8.6$ & $51.07 \pm 7.4$ & $50.9 \pm 7.76$ & N.St \\
\hline BMI $\left(\mathrm{kg} / \mathrm{m}^{2}\right)$ & $28.34 \pm 4.1$ & $29.4 \pm 5.5$ & $29.0 \pm 2.54$ & $28.6 \pm 2.3$ & N.S \\
\hline $\begin{array}{l}\text { Duration of } \\
\text { Therapy (yrs) }\end{array}$ & - & - & $2.12 \pm 1.5$ & $3.33 \pm 2.9$ & $.001^{*}$ \\
\hline $\begin{array}{l}\begin{array}{l}\text { Total Dose } \\
\text { (mg/day) }\end{array} \\
\end{array}$ & - & - & "500-1700 & $2.5-15$ & - \\
\hline
\end{tabular}

$\dagger$ Chi-square test.

\$ One-way ANOVA followed by Duncan's test.

* Unpaired t-test.

Fasting serum glucose and serum leptin concentrations appeared in Table (2). Concerning leptin; in metformin group, a significantly lower value was obtained when compared to control1, control-2 and glibenclamide groups. In glibenclamide group, a significantly higher value was 
obtained when compared to control-1 and metformin groups. Regarding FSG, it is obvious that a significantly lower value was found in control-1 group (non-diabetic subjects) when compared to other groups (diabetic patients).

Table 2: Fasting serum glucose and serum leptin concentrations.

\begin{tabular}{|c|c|c|c|c|}
\hline Groups & \multicolumn{4}{|c|}{ Mean \pm SD } \\
\hline Parameters & $\begin{array}{c}\begin{array}{c}\text { Control-1 } \\
\text { (Healthy) }\end{array} \\
(n=35)\end{array}$ & $\begin{array}{c}\text { Control-2 } \\
\text { (Newly diagnosed } \\
\text { T2DM) } \\
(\mathbf{n}=35)\end{array}$ & $\begin{array}{l}\text { Metformin } \\
\text { Group } \\
(\mathrm{n}=52)\end{array}$ & $\begin{array}{c}\text { Glibenclamide } \\
\text { Group } \\
(n=50)\end{array}$ \\
\hline Leptin (ng/ml) & $6.15 \pm 2.4$ & $7.56 \pm 3.8$ & & $9.17 \pm 4.9 * £$ \\
\hline FSG (mmol/L) & $5.60 \pm 1.01$ & $12.10 \pm 4.1^{*}$ & $9.35 \pm 3.75^{*} \dagger$ & $10.96 \pm 3.2^{*}$ \\
\hline
\end{tabular}

One-way ANOVA followed by Duncan's test.

* Significantly different compared to control-1 group.

† Significantly different compared to control-2 group.

$£$ Significantly different compared to metformin group.

There was a significant correlation between serum leptin level and BMI $(\mathrm{r}=0.206, p=$ 0.003 ) (Fig. 1). Non-significant correlation was found between serum leptin level and FSG $(\mathrm{r}=$ $-0.045, p=0.280)$.

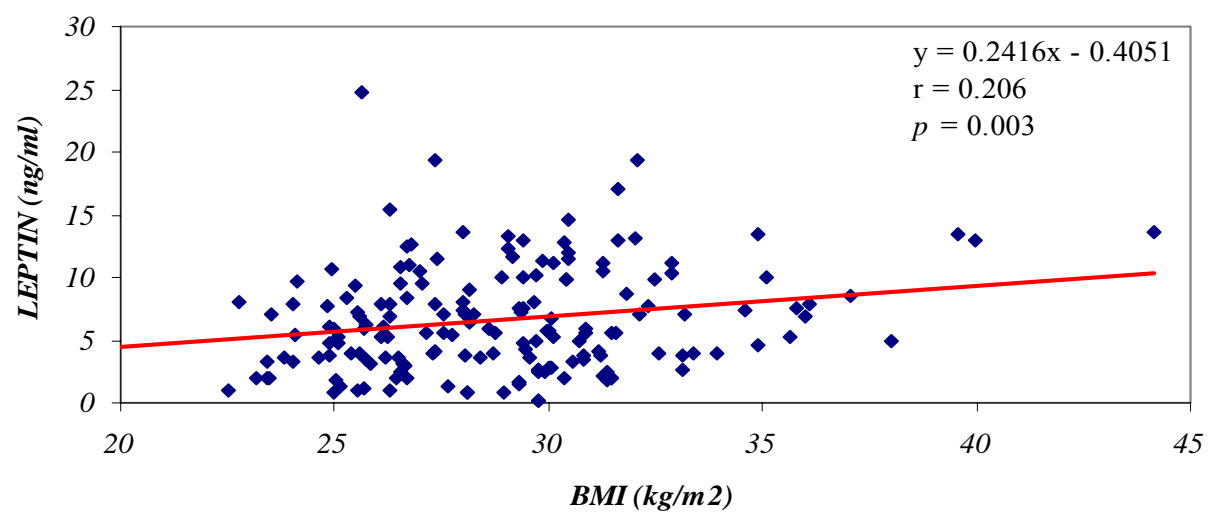

Fig. 1: Correlation of serum leptin concentration with BMI.

\section{DISCUSSION}

The present study revealed differences in serum leptin concentrations in the four groups although the four groups have closed BMI values. A significant correlation was found between serum leptin level and BMI but no correlation was found between leptin level and FSG.

Studies have indicated that leptin improves glucose homeostasis because leptin is involved in the regulation of glucose transport. The importance of glucose utilization becomes more 
important in metabolic disease states such as obesity and type 2 diabetes mellitus (Laimer et al., 2002; Gallardo et al., 2005).

A number of investigators determined serum leptin concentration in type 2 diabetic patients. Abdalla et al. (2010) reported that serum leptin concentration in non-obese type 2 diabetic patients was $5.66 \pm 0.29 \mathrm{ng} / \mathrm{ml}$ whereas a concentration of $5.05 \pm 0.41 \mathrm{ng} / \mathrm{ml}$ was obtained in obese (BMI $>30 \mathrm{~kg} / \mathrm{m}^{2}$ ) diabetic patients. Fox et al. (1999) reported serum leptin level of $14.3 \pm 2.5 \mathrm{ng} / \mathrm{ml}$ in diabetic obese patients and $14.9 \pm 2.8 \mathrm{ng} / \mathrm{ml}$ in non-diabetic obese patients. Bhattacharya et al., (2008) reported that fasting leptin level in type 2 diabetic patients with BMI value of $24.71 \mathrm{~kg} / \mathrm{m}^{2}$ was $3.74 \pm 1.02 \mathrm{ng} / \mathrm{ml}$.

In the present study, serum leptin concentration was significantly lowered in metformin treated group compared with the other groups. This may indicate that metformin therapy affects the level of leptin in blood. This result was in agreement with Fadil et al., (2011) who reported that the use of metformin alone in diabetic males for 90 days have significantly decrease serum leptin levels by about $40.6 \%$. Also, the treatment of diabetic females with different doses of metformin, significantly decreases the serum levels of leptin after 3 months treatment compared to baseline values $(P<0.05)$ (Kadhim et al., 2012).

Metformin has been reported to have no effect on the modestly reduced plasma leptin with short-term use (Uehara et al., 2001; Fruehwald-Schultes et al., 2002; Ardekani et al., 2008), and to reduce plasma leptin with long-term use (Glueck et al., 2001). In another study, the state of eighteen patients with T2DM were studied before and after 6 weeks of metformin treatment, no changes were detected in hunger, satiety or in fasting on adiponectin or leptin concentrations (Doogue et al., 2009).

In the present study, glibenclamide treated group showed the highest level of leptin concentration $(9.17 \pm 4.9 \mathrm{ng} / \mathrm{ml})$. The increase in leptin levels was related to the change in insulin levels caused by glibenclamide. This observation is in agreement with Haffner et al., (1991) who show that glibenclamide caused an increase in leptin level parallel to the change in insulin levels. In 30 patients with type 2 diabetes mellitus, Bhattacharya et al., (2008) showed a significant elevation in leptin level after treatment with glibenclamide for 10 weeks. Moreover, the treatment of diabetic males with glibenclamide alone for 90 days increases serum leptin levels significantly $(114.5 \%)$ compared to pretreatment value $(P<0.05)$ (Fadil et al., 2011).

In the present study, a significant positive correlation was found between serum leptin level and BMI, which was in agreement with many other studies (Misra et al., 2001; Buyukbese et al., 2004; Al-Shoumer et al., 2008).

\section{CONCLUSION}

This study showed that metformin, in contrast to glibenclamide, can significantly reduce the serum leptin concentration in overweight diabetic patients, reducing its resistance and improving its action, which may explain the known anorexigenic effect of metformin. So, plasma leptin level can be used as an indicator for the choice of treatment in those diabetic patients. 


\section{REFERENCES}

Abdalla, M.S.; Sharada, H.M.; Amin, A.I.; Samy, N.; Sayed, M.; Ashour, E. (2010). Association of serum leptin and adiponectin with atherosclerosis in obese and nonobese type 2 diabetes mellitus patients. J. Am. Sci., 6, 153-164.

Abdelgadir, M.; Elbagir, M.; Eltom, M.; Berne, C.; Ahren, B. (2002). Reduced leptin concentrations in subjects with type 2 diabetes mellitus in Sudan. Metabolism, 51, 304-306.

ADA, (2012). Diagnosis and Classification of Diabetes Mellitus. Diab Care, 35(1), S64-S71.

Al-Shoumer, K.A.; Al-Asousi, A.A.; Doi, S.A.; Vasanthy, B.A. (2008). Serum leptin and its relationship with metabolic variables in Arabs with type 2 diabetes mellitus. Ann Saudi Med., 28(5), 367-370.

Ardekani, J.M.; Didedar, R.; Babaei, A. (2008). Determination of the percentage of blood free leptin hormone in diabetic patients after treatment with metformin. Iranian J. Basic Med. Sci., 11, 86-90.

Aubert, G.; Mansuy, V.; Voirol, M.J.; Pellerin, L.; Pralong, F.P. (2011). The anorexigenic effects of metformin involve increases in hypothalamic leptin receptor expression. Metabolism Clinical and Experimental, 60, 327-334.

Bailey, C.J. (1992). Biguanides and NIDDM. Diab Care, 15, 755-772.

Bhattacharya, S.K.; Madan, M.; Hahajan, P.; Paudel, K.R.; Rauniar, G.P.; Das, B.P.; Roy, R.K. (2008). Relationship between plasma leptin and plasma insulin level in type 2 diabetic patients before and after treatment with glibenclamide and glimepiride. Indian $J$. Physiol. Pharmacol., 52, 43-52.

Buyukbese, M.A.; Cetinkaya, A.; Kocabas, R.; Guven, A.; Tarakcioglu, M. (2004). Leptin levels in obese women with and without type 2 diabetes mellitus. Mediators inflamm., 13, 321-325.

Correia, M.; Haynes, W. (2008). Does selective leptin resistance cause obesity-related hypertension? Rev Bras Hipertens; 15, 189-194.

Doogue, M.P.; Begg, E.J.; Moore, M.P.; Lunt H.; Pemberton, C.J.; Zhang, M. (2009). Metformin increases plasma ghrelin in Type 2 diabetes. Br. J. Clin. Pharmacol., 68, 875-882.

Fadil, T.A.; Khalaf, B.H.; Hussein, K.I.; Hussain, S.A. (2011). Effects of glibenclamide, metformin or their combination on the correlation between serum leptin levels with glycemic control and insulin levels in type 2 DM. J. Pharm. Biomed. Sci., 1, 23-28.

Fox, C.; Esparza, J.; Nicolson, M.; Bennett, P.H.; Schuiz, L.O.; Valencia, M. E. (1999). Plasma leptin concentrations in pima Indians living in drastically different environment. Diabetes Care, 22, 413-417.

Fruehwald-Schultes, B.; Oltmanns, K.M.; Toschek, B.; Sopke, S.; Kern, W.; Born J. (2002). Short term treatment with metformin decreases serum leptin concentration without affecting body weight and body fat control in normal weight healthy men. Metabolism, 51(4), 531-536. 
Gallardo, N.; Arribas, C.; Villar, M.; Ros, M.; Carrascosa, J.M., Martinez, C. ( 2005). ObRa and $\mathrm{ObRe}$ are differentially expressed in adipose tissue in aged food-restricted rates: Effects on circulating soluble leptin receptor levels. Endocrinol, 146, 4934-4942.

Glueck, C.J.; Fontaine, R.N.; Wang, P.; Subbiah, M.T.; Weber, K.; Illig, E. (2001). Metformin reduces weight, centripetal obesity, insulin, leptin, and low-density lipoprotein cholesterol in non-diabetic, morbidly obese subjects with body mass index greater than 30. Metab., 50, 856-861.

Haffner, S.M.; Hanefeld, M.; Fischer, S. (1991). Glibenclamide but not acarbose, increases leptin concentrations parallel to changes in insulin in subjects with NIDDM. Diabetes Care, 20, 430-434.

Hamed, E.; Zakary, M.; Ahmed, N.; Gamal, R. (2011). Circulating leptin and insulin in obese patients with and without type 2 diabetes mellitus: Relation to ghrelin and oxidative stress. Diabetes Research and Clinical Practice, 94, 434-441.

Kadhim, K.A.; Ismael, D.K.; Khalaf, B.H.; Hussein, K.I.; Zalzala, M.H.; Hussain, S.A. (2012). Dose-dependent relationship between serum metformin levels and glycemic control, insulin resistance and leptin levels in females newly diagnosed with type 2 diabetes mellitus. J. Diabetes Mellitus, 2, 179-185.

Kwalska, I.; Straczkowski, M.; Kinalska, I. (1998). Levels of leptin in plasma of patients with type 2 diabetes. Pol Arch. Med. Wewn., 99, 470-476, Abstract Pub Med.

Laimer, C.F.; Ebenbichler, S.; Kaser, A.; Sandhofer, H.; Weiss, H.; Nehoda, F. (2002). Weight loss increases soluble leptin receptor levels and the soluble receptor bound fraction of leptin. Obes. Res., 10, 597-601.

Laxmi, M.S.; Venkatesham, A.; Reddy, A.N.; Shankaraiah, P.; Krishna, D.R.; Reddy, Y.N. (2009). Glibenclamide Therapy in Type 2 Diabetes. International J. Pharmaceutical Sci. Nanotechnol., 2(1), 465-470.

Lebovitz, H. (2002). Treating hyperglycemia in type 2 diabetes: New goals and strategies. Cleveland Clinic J. Medicine, 69, 809-820.

Misra, A.; Arora, N.; Mondal, S.; Pandey, R.M.; Jailk hani, B.; Peshin, S. (2001). Relation between plasma leptin and artropometric and metabolic covariates in lean and obese diabetic and hyperlipidaemic Asian Northern Indian subjects. Diabetes Nutr. Metab., 14, 18-26.

Uehara, M.H.; Kohlmann, N.E.B.; Zanella, M.T.; Ferreira, S.R.G. (2001). Metabolic and haemodynamic effects of metformin in patients with type 2 diabetes mellitus and hypertension. Diabetes Obes Metab., 3, 319-325.

Zhang, F.; Chen, Y.; Heiman, M.; Dimarchi, R. (2005). Leptin: Structure, function and biology. Vitam Horm., 71, 345-372. 